\title{
Eastern Strawberry Breeders: Personal Recollections
}

\author{
K.S. Lewers \\ U.S. Department of Agriculture, Agricultural Research Service, Beltsville Agricultural Research Center-West, Fruit \\ Laboratory, Room 210, Building 010A, 10300 Baltimore Avenue, Beltsville, MD 20705
}

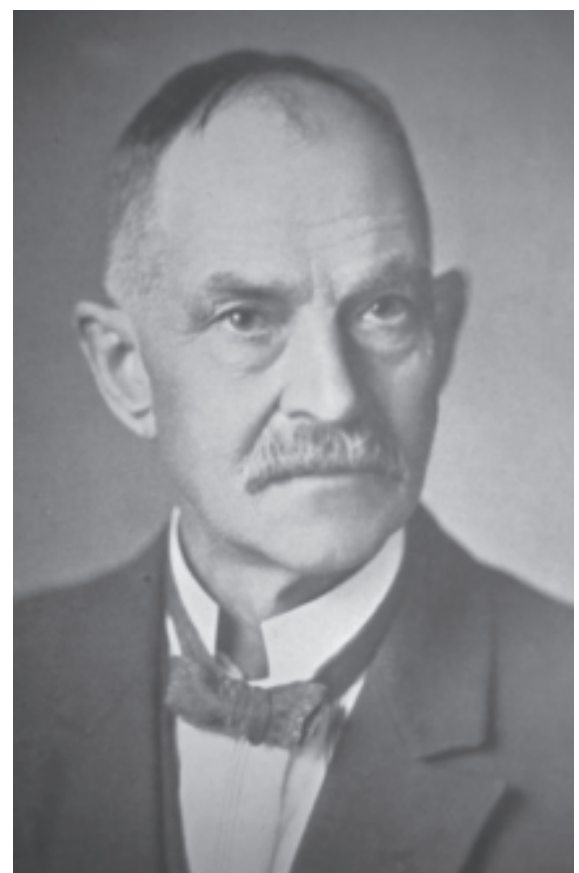

Fig. 1. Walter van Fleet.

The recollections of the following strawberry breeders of eastern North America were obtained from interviews with collaborators, colleagues, friends, neighbors, and family. They reveal extraordinary personalities, who loved life and horticulture.

\section{WALTER VAN FLEET}

Walter van Fleet (1857-1922), although trained as a naturalist and physician, turned to plant breeding at age 35 , apparently led by his love of the roses he remembered from his childhood (Fig. 1). He was best known for his work with roses and blight-resistant chestnuts, but also worked with gladioli, cannas, raspberries, and strawberries. His sister, Florence, his closest childhood companion, said, "He was not egotistical, and he was self-sacrificing, so the others came first, and in that way, he earned their abiding faith in him." At age 53, he joined the U.S. Department of Agriculture. At one point, new land was needed, and he took a D.C. trolley to its end point at Glen Dale, Md., to establish serendipitously a new research site where he, and later George Darrow, conducted their strawberry research.

\section{GEORGE DARROW}

George Darrow (1889-1983), a dynamo of energy completely absorbed by plant breeding, lived adjacent to the Glen Dale research station (Fig. 2). His efforts to incorporate multiple species into the strawberry breeding program, use large numbers of cross-pollinations, and evalu-

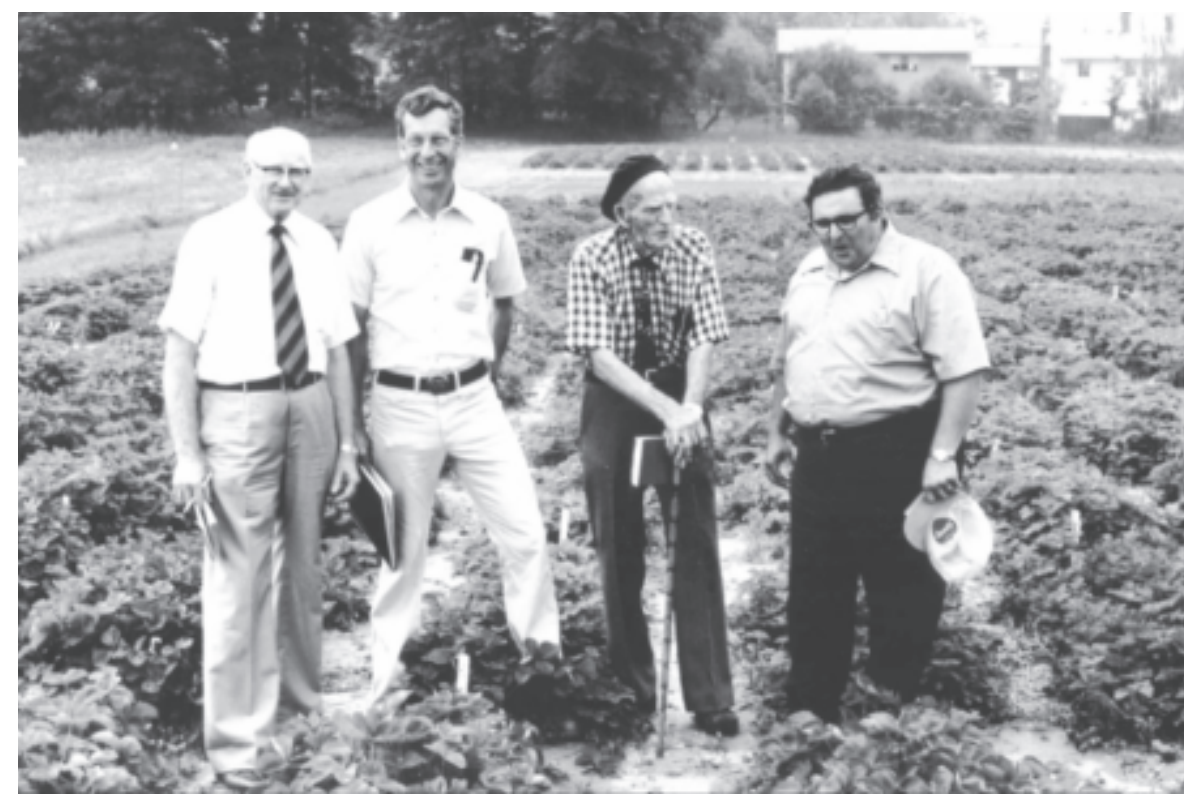

Fig. 2. Donald Scott, Arlen Draper, George Darrow, and Gene Galletta (left to right).

ate large numbers of progeny per cross yielded high-quality selections for many years to come. His productivity was sustained well beyond his retirement as evidenced by his establishment of the first U-pick operation at his home in Glen Dale; his involvement as president of the Beltsville Garden Club (founded by colleague Don Scott); and his establishment of a daylily breeding and nursery business continued today by his grandchildren in Vermont.

\section{EMMETT BROWN MORROW}

Emmett Brown Morrow (1898-1956), of North Carolina State University, was described by many as always being the very proper

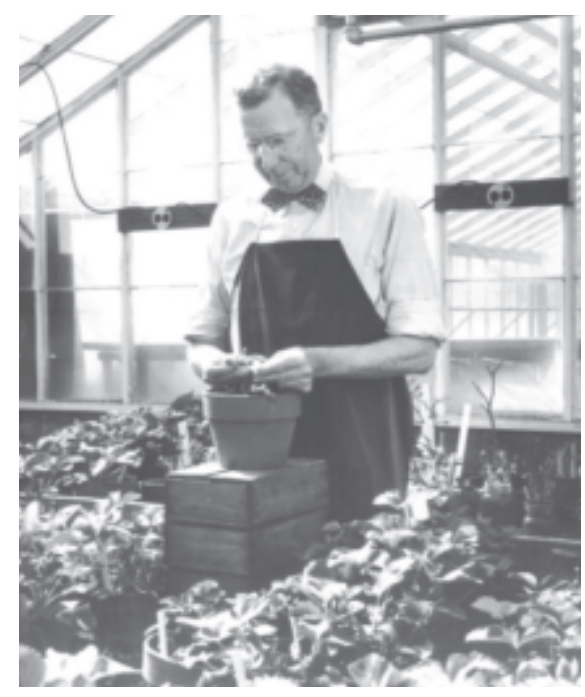

Fig. 3. Emmett Brown Morrow. gentleman, characteristic of the times in which he lived (Fig. 3). He wore a white shirt and tie even when working in the field during those very warm and humid Carolina summers, according to Jim Ballington. Both Ballington and Darrow noted him as having produced few but highly significant publications before his early death at 58 .

\section{DONALD H. SCOTT}

Don Scott(1911-1998) worked for 11 years as geneticist with George Darrow before taking over the program in 1957 (Fig. 2). According to neighbor, Bob Yaklich, Scott was a fine gentleman and a pleasure to know. He was very respectful of others and was careful with expenditures. Like Darrow and van Fleet, Scott worked with other plants as a hobby. He bred daylilies and azaleas and sold them at plant sales through the Beltsville Garden Club that he founded. Scott had a bit of prankster in him, too. He enjoyed demonstrating that a firm berry was firm only by berry standards by squashing it in his hand, or enticing a colleague to taste a particularly sour seedling. This gentle fun has been appreciated by the strawberry breeders who followed in his footsteps.

\section{CHARLES LEWIS RICKETSON}

Lew Ricketson (born in 1932), ofCanada's strawberry breeding program, is noted by Andrew Jamieson as "a hard worker and always worked along with his crew, getting his hands dirty. He is a great guy and drops into the station on occasion to say hello, and to see what is new in berry cultivars." (Fig. 4). 


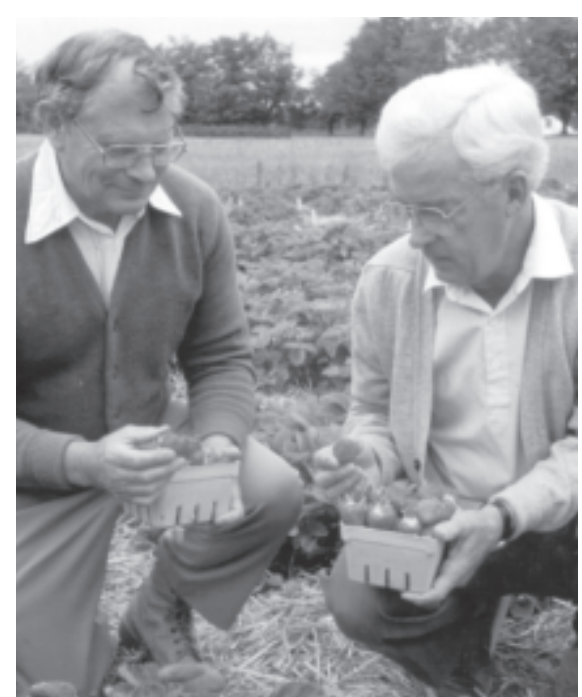

Fig. 4. Charles Lewis Ricketson and Donald Craig.

\section{DONALD CRAIG}

Don Craig (born in 1923), also of Canada, is another strawberry breeder who has worked on other plants during his career and on rhododendrons after retirement. He once confided to Andrew Jamieson that he didn't really like strawberries but preferred raspberries. (Fig. 4).

\section{JOHN SANFORD}

John Sanford (born in 1949) of Cornell University is best described as humble, calm, thoughtful, modest, and a thinker or dreamer according to former technician, Kevin Maloney. Even after the invention of the gene gun, his demeanor hasn't changed, nor has his lifestyle. On his office door, Sanford had the word, "simplify," and he liked keeping procedures easy to follow. He was very good at organizing and encouraging a large lab of people to work together. Although noted most for inventing the gene gun (Fig. 5), Sanford enjoyed small fruit breeding and loved field evaluations of berries. His favorite hobbies are listening to and playing music. He also enjoys playing soccer, and set up a soccer night for the lab. Maloney attributes Sanford's calm and relaxed manor to his faith, which he takes very seriously.

\section{ARLEN DRAPER}

Arlen Draper (born in 1930) began as a small fruit breeder who worked on many crops and has continued to be extremely productive after official retirement from the USDA(Fig. 2).

It was said of him that, blueberry, rather than strawberry, was "his first love." He carried on Don Scott's tradition of enticing his associates at the Beltsville Fruit Laboratory to taste fruit from the really sour seedlings.

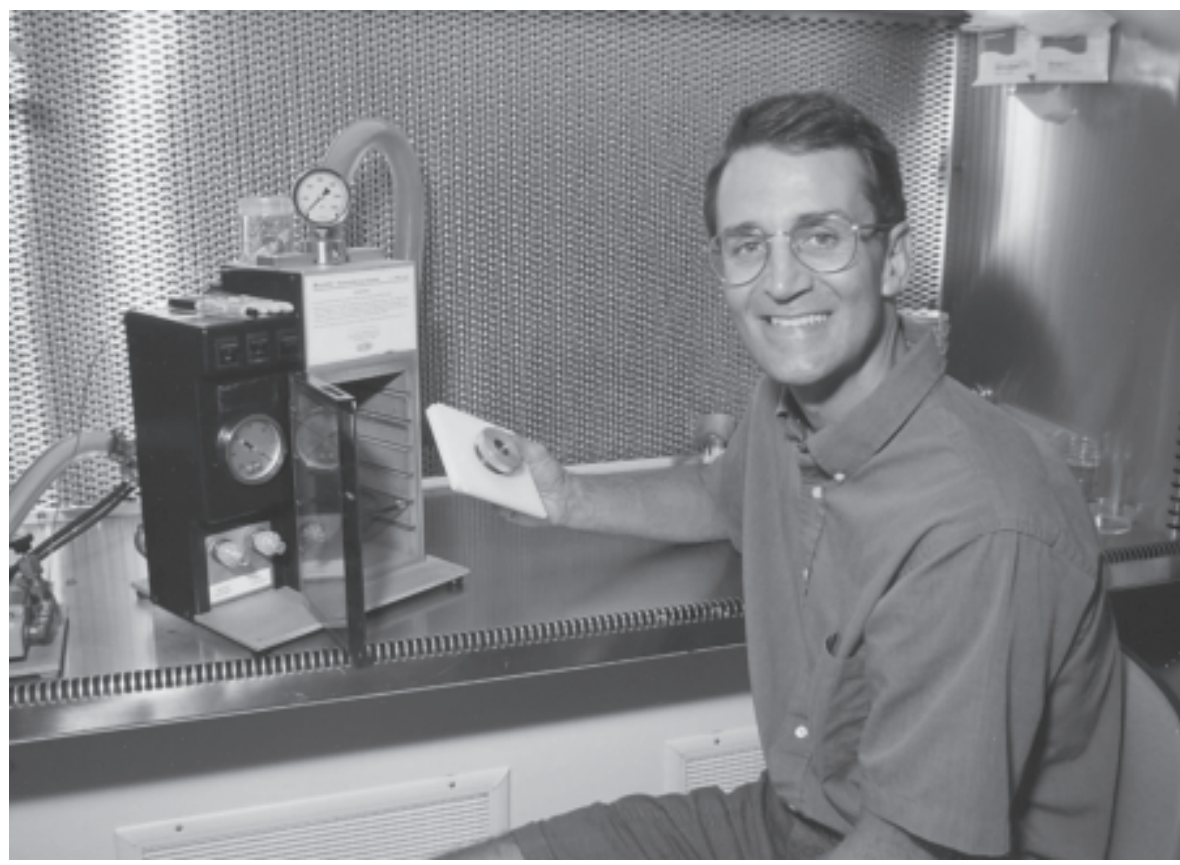

Fig. 5. John Sanford and his gene gun.

\section{GENE GALLETTA}

Gene Galletta (1929-2002) had an uncanny way of getting technical information across to individuals untrained in breeding and genetics by using everyday examples to which they could relate (Fig. 2). The Beltsville Fruit Lab remembers him as having tremendous energy and that he was difficult to keep up with in the field. Galletta seemed to have fun with every aspect of life. He was noted for singing in the field as well as with his barbershop quartet and in church. He was a gentle man and he called the ground hogs who damaged his plots "bad boys." His close colleague, John Maas, noted that' "the best thing about traveling with Gene was that, wherever we were in the world, he could always find the best Italian restaurant."

\section{HENRY A. WALLACE}

Henry Wallace (1888-1965), a corn breeder who founded the Pioneer Seed Company, became vice president of the United States (1940-1944) under Presidency Franklin Roosevelt and was an unsuccessful candidate for the presidency in 1948 (Fig. 6). After his retirement he went back to strawberry breeding because of the influence of his friend George Darrow. Wallace said, "...Continually, I crossbreed strawberries and grow them from seed. Each year I wait to see what they look like the next year. I recommend to all of you that you become gardeners. Then you will never die, because you have to live to see what happens next year."

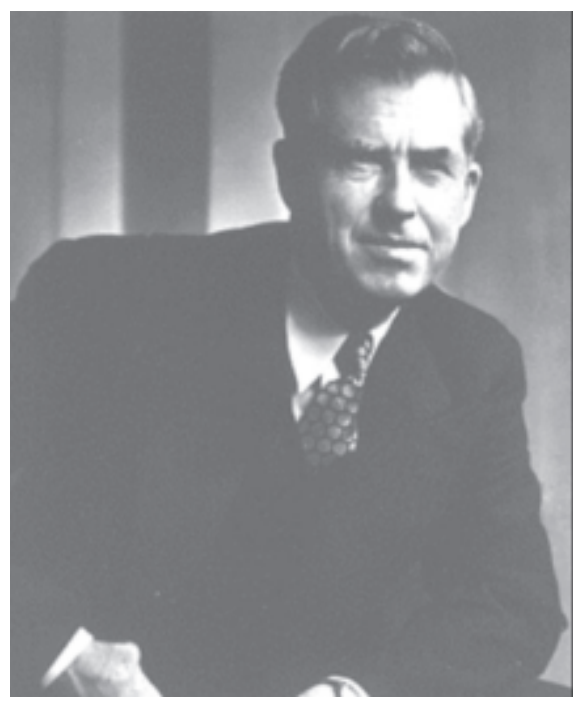

Fig. 6. Henry A. Wallace. 